\title{
Impact of the Trade Union Act 1984 on the BMA
}

\author{
NORMAN ELLIS
}

When the Conservative administration entered office in June 1979 it was widely believed that the tide of industrial relations legislation would recede. Such an assumption could not have been more mistaken: since 1979 the government has enacted three important and extensive pieces of legislation in this areathe Employment Acts of 1980 and 1982 and the Trade Union Act $1984 . .^{1-3}$ All these are intended to alter radically the behaviour of trade unions and their members.

For the most part professional bodies such as the BMA have been able to observe these changes in employment law from a safe distance; the new legislation on the legality of strikes and picketing was not seen to have any direct bearing on an organisatıon whose members were unlikely to take part in (or even contemplate) such activities. The main thrust of the legislation was seen to be aimed at the industrial unions, not professional bodies.

This pattern was broken by the Trade Union Act 1984, in particular by that part of it that establishes new rules for the election of executive bodies of trade unions. When the government published its green paper Democracy in Trade Unions in January 1983 the BMA initially assumed that its highly democratic procedures more than satisfied the principles of trade union democracy enunciated in the discussion paper: "voting invariably takes place in conditions of secrecy; all members eligible to vote have the opportunity to do so under a system which provides the best opportunity of a reasonable turn out; all votes are counted fairly; and those who take decisions at the highest levels are properly representative of, and accountable to, the membership as a whole." 4

Indeed, was not the BMA, in the words of the celebrated historians Beatrice and Sidney Webb, "one of the most highly developed and efficient of all British professional organisations" with a "complicated constitution," which included "all the devices of advanced democracy"? Thus we could continue to believe that the government's proposed legislation was not directed at the medical profession's representative organisation.

When the Trade Union Bill was published, however, it was based on more specific and rigorous principles than those first enunciated. The Bill laid down three main provisions for democracy that every trade union would have to satisfy: that members of a trade union should be able to elect their "principal executive committee" by secret ballot; that there should be consultation with members in a secret ballot before industrial action is taken; and that members should vote at least once every 10 years on whether their union should maintain a political fund. Only the first of these proposals was likely to affect the BMA to any extent. In this area the government's proposals were more specific in that the new legislation would require elections to the governing bodies of trade unions-that is, their principal executive committees-to be conducted in accordance with the following basic principles:

- Voting must be secret.

- Voting must be by the marking of a ballot paper.

- Every member must have an equal and unrestricted opportunity to vote.

- Each member must be able to vote directly for members of the governing body.

British Medical Association, BMA House, Tavistock Square, London WC1H 9JP

NORMAN ELLIS, MA, PHD, under secretary
In particular, the last two principles would not permit the election of a trade union governing body by the membership of any intermediate body-for example, by the representative body of the BMA or any of its craft committees.

It was quite clear that the council would be regarded as the "principal executive committee" of the BMA for the purposes of this legislation, and that its constitution would have to be radically changed. This should not be confused with the present executive committee of the BMA's council, since this has functions that should not be regarded as those of a principal executive committee of a union. The BMA sought to persuade ministers and officials that the present constitution of the council was democratic and that the changes required by the Bill would not improve the representation of crafts, and occupational and geographical interests on it. The government was determined to see the Bill implemented and, unlike with the Industrial Relations Act of 1971, was not prepared to amend it to accommodate the special position of professional bodies such as the BMA. At present none of the 60 members of the council is directly elected by the members (see box).

The Trade Union Bill received the royal assent in July, and the part that requires changes to be made in the way in which members of the council are elected becomes operative on 1 October 1985. Thus amendments to the articles and bylaws will need to be considered by the annual representative meeting in 1985 and new arrangements for electing the council will start during the session 1986-7. The Act requires that these new arrangements should apply to the first election held after 1 October 1985. Thus the election of the council next year for the 1985-6 session will be the last one to be run on present lines.

\section{What changes are required?}

The overriding principle on which changes in the constitution must be based is that all voting members of the council must be directly elected by a secret ballot of members. Any other members of the council, who are there by virtue of the offices they hold, cannot vote unless they are elected in this manner. But the Act does allow a union to set up different "constituencies" for members of its executive committee. In the BMA these can be defined on a geographical and occupational basis. Thus the 17 regional members of the council could be elected by postal ballots of members in each region, and those members who represent the various crafts (general practice, hospital senior staff, hospital junior staff, community medicine and community health, armed forces, medical academic staff, occupational health) could be elected by a plebiscite of BMA members in the relevant branch of medical practice. In addition, the four other members of the representative body elected by the representative body could in future be elected by a ballot of the whole membership.

There are two other categories of council members that are not easily accommodated in these new arrangements. Firstly, there are the chairmen of various committees for which there is no craft constituency - that is, the board of science and education, central ethical committee, charities committee, journal committee, junior members forum, organisation committee, private practice and professional fees committee, and superannuation committee. In each case it has been suggested that the committee chairman should be a non-voting member of the council, unless he or she is elected in a voting capacity from some other constituency. Secondly, there is the 
position of the chief officers of the association, who are exofficio members of the council: the chairman and deputy chairman of the representative body, the treasurer, and the immediate past chief officers for one year after leaving office. Again a similar solution has been proposed: that these office

\section{BMA council: its present composition}

\section{Ex-officio}

\section{(a) Chief officers:}

President, chairman of the representative body, deputy chairman of the representative body, chairman of council, treasurer (and the immediate past chairman of the representative body, chairman of council, and treasurer, for one year after ceasing to hold office).

(b) Committee chairmen:

The chairmen of the following:

Armed forces committee, board of science and education, Central Committee for Hospital Medical Services, Central Committee for Community Medicine and Community Health, central ethical committee, charities committee, General Medical Services Committee, Hospital Junior Staff Committee, journal committee, junior members forum, Medical Academic Staff Committee, Northern Ireland council, occupational health committee, organisation committee, private practice and professional fees committee, Scottish council, superannuation committee, and Welsh council.

\section{Appointed members}

One member each appointed by the following committees :

Armed forces committee, Central Committee for Hospital Medical Services, General Medical Services Committee, Hospital Junior Staff Committee, Medical Academic Staff Committee, and occupational health committee.

\section{Elected members}

A total of 31 elected by the representative body as follows:

Four members of the General Medical Services Committee.

Two members of the Central Committee for Hospital Medical Services.

Three members of the Hospital Junior Staff Committee.

One member of the Central Committee for Community Medicine and Community Health.

These members are nominated and elected by those members of the representative body employed predominantly in the same category of medical practice.

Seventeen members of the representative body representing (one each) Wales, Scotland, Northern Ireland, and the 14 NHS regions of England.

Four other members of the representative body (in any category).

These members are elected by the representative body as a whole, but, in the case of the regional representatives, nominations must be by a member of the representative body from the same region. holders should be non-voting members of the council, unless of course they are elected to serve in a voting capacity.

The voting rights of the present chairman of council and the treasurer are safeguarded as they were elected for a three year term before the Act; they will continue to have a vote for the remainder of their periods of office.

These changes in the arrangements for electing the BMA council will be costly to administer; an extensive and complex postal ballot of members will have to be administered. The government, however, will finance postal ballots; this is provided under the Employment Act 1980.

\section{Consequences}

The new electorate arrangements may encourage those doctors who are already active in medicopolitics to adopt a higher profile. Their visibility among the wider audience of members, whether in a geographical or an occupational constituency, could influence the outcome of these elections. There is also the possibility that those doctors elected from a craft constituency will not necessarily be the same people as those who already hold the principal elected offices in the corresponding craft committee. This eventuality may not be quite as improbable as it may sound. The General Medical Council elections earlier this year had some surprising results, particularly in the English constituency. At least the BMA elections will not require electors to choose in order of preference 39 candidates from a field of 169 . The largest number of vacancies in any single constituency is likely to be six, and in any craft constituency it may be possible to identify those candidates who already serve as the principal officers of the craft committees.

The most immediate effects of these changes may be felt in the geographical constituencies. The activity of BMA regional councils varies from one part of the country to another. Some regional councils meet regularly and important issues of common concern are discussed; there is often a strong sense of regional identity. In other areas it has been an uphill (and often unrewarding) task; regional councils have met only infrequently and attendances have been poor. It is possible that the introduction of these regional constituencies may give a much needed impetus and breathe new life into regional councils.

Finally, it would seem that this Trade Union Act puts the BMA, a body with both professional and trade union functions and responsibilities, in precisely the obverse position to that prevailing before the 1971 Industrial Relations Act. Many members will recall the British Medical Guild, a somewhat elusive and shadowy body into which the BMA council would transform itself when dealing with trade union matters that would have been constitutionally illegal for the council to discuss. Perhaps in the new circumstances of the 1984 Trade Union Act an analogous device could be introduced to enable all members of the BMA council, both voting and non-voting, to take decisions on matters of an ethical, professional, or scientific nature outside its trade union responsibilities.

It may seem odd, to say the least, if chairmen of the central ethical and organisation committees, for example, present their reports, take part in debates on any recommendation, but are precluded from voting on the outcome. If the BMA council was empowered to transform itself into, say, the "BMA professional council" this would enable all its members to participate fully in its deliberations on professional and scientific matters. Such a change would ensure that the BMA could continue to fulfil its important dual function as professional body and trade union despite the new legislation.

\section{References}

1 Employment Act 1980. London: HMSO, 1980

2 Employment Act 1982. London: HMSO, 1982.

4 Department of Employment. Democracy in trade unions. London: HMSO, 1983. (Cmnd 8778.) 
annual report setting out developments in the area and the guidelines being operated for approval and rejection of projects. Mr Meacher supported the Warnock committee's wish to ban surrogacy for profit and believed that it was justified only in exceptional circumstances -for example, if the mother was disabled.

Sir Bernard Braine called the use of the embryo for experimentation an affront to humanity and said that there was no room for compromise.

A former Minister for Health, Sir Gerard Vaughan, said that it was unacceptable to bank fertilised ova and to experiment on human embryos, even for the first 14 days. "If we do not act with authority, and rapidly, we shall find that scientific experiments intended for one purpose only have already rushed ahead of what is acceptable."

$\mathrm{Mr}$ Michael Meadowcroft suspected that there would be support in the House for the view that there needed to be considerable lay representation on any licensing authority rather than risk it being dominated by either the medical profession or others with scientific backgrounds.

In Mrs Renée Short's view the question of experiments on human embryos was a matter for individuals to decide. She told the House, "The expert bodies and witnesses called before the committee and the committee's evidence and recommendations present us with the basis of a proper scientific and legal set of rules and safeguards which I hope the whole House will accept. I hope that the Home Secretary will take on board the clarification of some of the difficult legal issues that are involved in in vitro fertilisation."

But Mrs Elizabeth Peacock hoped that the government would act to limit all forms of experiment or research and ban all forms of in vitro fertilisation except where the wife's ovum was fertilised by her husband and replaced in her womb. Mrs Jill Knight said that for the House to allow experimentation on human embryos would be a terrible step. She quoted the president of the Royal College of General Practitioners who said: "General practitioners are in a unique position to balance the debate between public and medical specialists. Our view is that experimentation would be to the detriment of society, overwhelming any progress made. Too many problems are involved when you start blurring the time at which you decide the embryo should be given full status."

\section{Reference}

1 Committee of Inquiry into Human Fertilisation and Embryology. Report. London: HMSO, 1984.

Mrs Renée Short, who told the House that ex periments on human embryos was a matter for individuals to decide.

The chief Opposition spokesman, $\mathrm{Mr}$ Michael Meacher, agreed that changes in knowledge, techniques, and cultural attitudes might well mean that medical codes of practice and legal sanctions would require constant review. In his view the issues under discussion could be determined only by individual conscience. $\mathrm{Mr}$ Meacher doubted whether it was wise to enshrine in statute a precise time limit for experimentation. There needed to be flexibility and he supported a licensing authority. This should be equipped with statutory powers to maintain the research and treatment within strict and enforceable boundaries of control. It should publish an
The BMA had insisted that there should be no relaxation of the cremation procedure until the system of death certification had been dealt with. At present this system merely provides epidemiological information about the cause of death and is a gratuitous service provided by the doctor attending the deceased person during the last illness.

The BMA secretary and the Home Office had corresponded on the matter and on 30 October Mr J R A Chawner, chairman of the BMA's forensic medicine subcommittee, led a delegation to meet the Home Office minister, Mr David Mellor. The delegation put to the minister the BMA's concern that the form $C$ should be retained until the conditions required to complete a death certificate had been strengthened.

$\mathrm{Mr}$ Mellor agreed to consider the points made by the BMA and gave an undertaking that in the event of legislation being proposed there would be opportunity for further consultation. He pointed out that the Home Office had to take account of how the facts were perceived in the minds of the public. The BMA was heartened by his comments about the need to implement another of the Brodrick report's recommendations-namely, to bring about a centrally administered coroners' service.

\section{Minimum standards for surgery premises}

A health notice will shortly be issued to family practitioner committees giving guidance to general practitioners on the discharge of their responsibilities regarding the provision of surgery premises. It will cover the provision of advice on improving premises, arrangements for visiting, the application of revised guidance on minimum standards, the withholding or abatement of rent and rates-after due notice and consultation-where premises do not reach an acceptable standard, and the submission by family practitioner committees of information on the operation of the guidance. Appropriate amendments to the statement of fees and allowances will be made which will also make clear that where rent and rates are withheld or abated the doctor may make representations to the Secretary of State.

\section{"The Occupational Physician"}

The BMA has published the third edition of the booklet The Occupational Physician, which was revised in 1981. This gives detailed guidance on the role of the doctor who gives medical advice to industry, commerce, and the public sector. There are chapters on contracts of employment, liaison with outside bodies, and relations with occupational health nurses. In a supplement the BMA has set out the recommended whole time and a range of part time salary scales for occupational physicians. The booklet is available to members from the secretary of the occupational health committee, free of charge. The price to non-members is $£ 3.50$. 